\title{
DETERMINATION THE IMPORTANCE OF THE PROBLEMS IN ENTREPRENEURSHIP BY FUZZY AHP - APPLICATION WITH FUZZY TOPSIS
}

Onur Kurtçu

\author{
Industrial Engineering Department \\ Sakarya University \\ Sakarya, TURKEY \\ E-mail: onurkurtu@yahoo.com \\ Assistant Professor Dr. Esra Tekez \\ Industrial Engineering Department \\ Sakarya University \\ Sakarya, TURKEY \\ E-mail: etekez@sakarya.edu.tr
}

\begin{abstract}
Fuzzy AHP and fuzzy TOPSIS methods are decision-making way at the end of integrating the current methods with fuzzy structure. In this study, the problems of enterpreneurs are discussed and the popular factors in these processes aimed to determine in a systematic way. At this point, it is asked to compare the problem's criteria with each other by using linguistic scale in fuzzy AHP method. At the end of the judgement, the weights of the criterion are determined and ranked as to importance point. After determining top problem factors, the sector analysis of the enterpreneurs is completed with fuzzy TOPSIS method. The proposed model enables new enterpreneurs to better understand the difficulties of the related processes and help to design road map to proceed in efficient way
\end{abstract}

Keywords: Entrepreneurship, Fuzzy AHP, Fuzzy TOPSIS

\section{Introduction}

It is generally known that entrepreneurs are face to face several problems at building up business. The important point for reaching professionalizm in entrepreneurship and gaining more points of view is analyzing the current problems in detail. Hereby, the main structure must be investigated the detailes of the problems and has to be revealed the analytical approaches.

In this study, the current problems and sub criterias related with the problems of entrepreneurship are defined in detail way. At the stage of building the business, the basic problems are classified in three groups, marketing-sale, production/service and financial management. After that, the sub issues are determined for each group and offer the enterpreneurs, experts and surveyors to compare the criterias according to the linguistic scales. The obtained results are analyzed with Fuzzy AHP method and the problem criterias are ranked to the importance degree.

In second part of the study, the criterias are assessed with the enterpreneurs in various sector areas. In their business, they compare the criterias that are determined as to importance degree. At this point, Fuzzy TOPSIS method is applied to make analysis to determine the difficulties for each sector.

\section{Literature Review}

There are some studies that investigated problems and challenges for entrepreneurship. One of them is related with the identifying the main obstacles and difficulties the entrepreneurship in Romania.[1] The other research presents the identifying the challenges companies encounter and discussing how is managed these challenges efficiently.[2] 
It is possible to use fuzzy logic in various areas through developing as washing machine, vacuum cleaner, braking system ex. In fuzzy logic, it is not only taken care white and black colurs but also grey tones as well. This approach is nearly same with human conception system. At this point, triangular fuzzy numbers are considered with the triangle in reel numbers. In this way, the difference of fuzzy number from triangle structure is creating the fuzzy numbers as lower to upper that every number has three elements, the first one expresses lower value, second one points out the middle value (optimal), and the other is related with the upper value[3].As AHP, which is one of the multiple-criteria-decision making method is not useful for the decision on uncertain times, Fuzzy AHP Method has been designed by

combining AHP and fuzzy logic. Decision-makers considers the discrete analysis as confidential than making the definite assessment.

AHP is used in multi-criteria decision-making methods. At this point, Wei, Chien, and Wang (2005) offered a system for selecting an ERP system that was resulted at the end of AHPbased decision analysis process.[4] In addition to this, AHP is easier to understand and keep the qualitative and quantitative data. Moreover, supply chain applications in the Australian textiles, clothing and footwear industry were defined by Perry, Sohal, and Rumpf (1999)[5] In our research, the current problems related with the problems of entrepreneurship are defined in detail way and asked the entrepeneurs to compare the criterias. The obtained results are analyzed with Fuzzy AHP method and the problem criterias are ranked to the importance degree.

TOPSIS method is generally used for completing ranking problems in real environment. Normally, personal judgements are represented with crisp values in TOPSIS applications. As the human preference model is indefinite and decision- makers are unable to assign crisp values to the comparison judgments in several cases. [6] Fuzzy TOPSIS and its models are applied to solve ranking problems[7] and are used triangular fuzzy number for fuzzy TOPSIS as they are generally easy for the decision-makers to use and calculate. In this study, it is analyzed to compare the difficulties of various sectors in which entrepreneurs can be face to face in daily life by using Fuzzy TOPSIS.

\section{Hypotheses/Objectives}

As strategic management researchers have traditionally focused on growth-oriented strategies for small firms [8], the firms have to struggle with the problems to prevent the negative effects. In developing the entrepreneurship applications day by day, the problems in this system are assessed in advance and are taken required actions is critically important for the long life business. The results obtained at the end of the study presents the main ideas related with the problem criterias. Therefore, it provides the general information for the enterpreneurs, get them to learn the problems in advance and help to make the road map to know which problems they must give priority to solve. Also, it is considered that several specific inferences can be obtained in each sector.

\section{Research Design/Methodology}

In this study, the general methodology is given in Figure 4.1. The methodology is defined as two sections including the Fuzzy AHP and Fuzzy TOPSIS method. First of all, all criterion that affect the enterpreneurs at building the business and business proceed (during the first times) has been discussed by all experts (committee, experts, assistant of experts, sector officials, some enterpreneurs exc.) Secondly, the enterpreneurs in various sector discuss the determined criteria and judged the criteria in their process area. In this part, it is analyzed with Fuzzy TOPSIS method. 
Figure 4.1 General Methodology

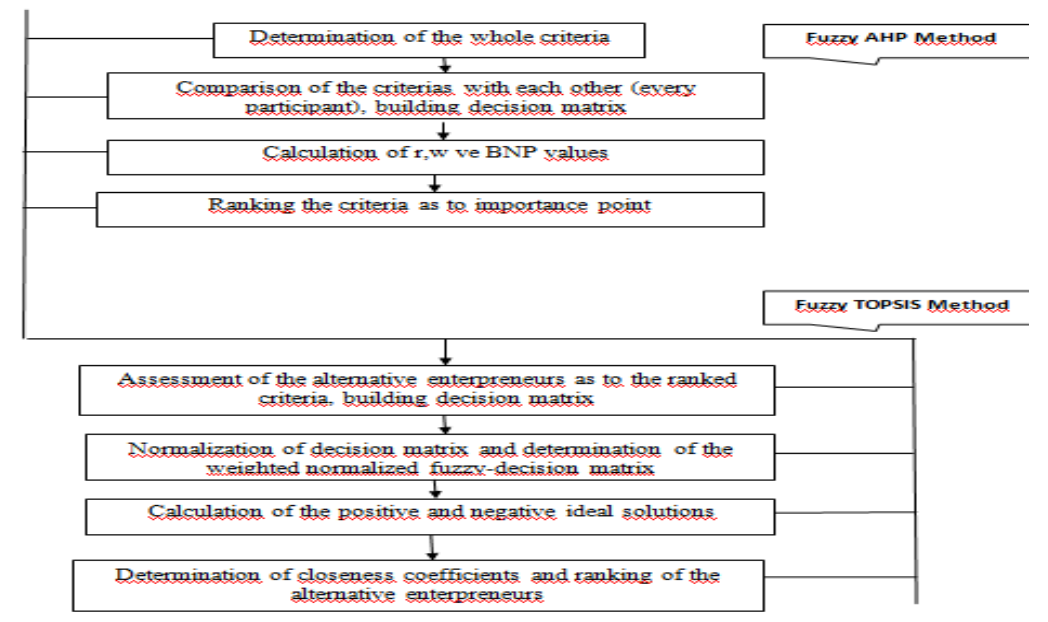

\section{Data/Model Analysis}

In this study, the most important problems on building a new business are discussed in comparing the criteria with each other. At this point, eight participants of the assessment make comparison as using the linguistics scale. The general table including the details of each ciriterion is given in Table 5.1.(The first problem factors are formed with the experts and committee members)

After the construction of this table, the different priority weights of each criteria, attributes and alternatives are calculated using the fuzzy AHP and fuzzy TOPSIS approaches. The comparison of the importance or preference of one criterion, attribute or alternative over another can be done with the help of the questionnaire. The method of calculating priority weights of the different decision alternatives is discussed below.

\section{Step 1: The weights of evaluation criteria}

It is designed the fuzzy AHP the weights of different dimensions for the ranking of the problems that enterpreneurs (given Table 5.1) are generally face to face on building a new business. Following the construction of fuzzy AHP model, it is extremely important that participants fill the judgment matrix. The following section demonstrates the computational procedure of the weights of dimensions.

Table 5.1 General Information of Criteria

\begin{tabular}{|c|c|c|c|}
\hline Code & Criterion & Sub-Criterion & Criterion Deficiency \\
\hline DE & \multirow[b]{4}{*}{$\begin{array}{l}\text { MARKETING-SALES } \\
\text { MANAGEMENT }\end{array}$} & Delivery Efficiency & Delivery product with right quantity and quality on time \\
\hline CA & & $\begin{array}{l}\text { Competition } \\
\text { Analysis }\end{array}$ & $\begin{array}{l}\text { Assessment of the rival companies, product/service's level and } \\
\text { characteristics of them (sales price, discount rate, payment system exc.) }\end{array}$ \\
\hline MA & & $\begin{array}{l}\text { Marketing- } \\
\text { Advertising }\end{array}$ & $\begin{array}{l}\text { Advertising and marketing organizations at the point of increasing the sales } \\
\text { and brand awareness (advertisings, billboard adv.,survey exc.) }\end{array}$ \\
\hline CAV & & $\begin{array}{l}\text { Customer } \\
\text { Availability }\end{array}$ & $\begin{array}{l}\text { Determination the customers of the products/service, research of the } \\
\text { potantial customer }\end{array}$ \\
\hline PS & \multirow[b]{4}{*}{$\begin{array}{l}\text { PRODUCTION/SERVICE } \\
\text { MANAGEMENT }\end{array}$} & $\begin{array}{l}\text { Production/Service } \\
\text { System }\end{array}$ & $\begin{array}{l}\text { Designing of the production/service and building the area, supplying of the } \\
\text { machine-equipment materials and getting legal permissions }\end{array}$ \\
\hline SRM & & $\begin{array}{c}\text { Supplying of Raw } \\
\text { Material }\end{array}$ & Planning of raw materials, making order and supplying the order \\
\hline $\mathbf{P Q}$ & & Product Quality & Having right quality standart of the product and eliminating the defects \\
\hline HRM & & $\begin{array}{l}\text { Human Resource } \\
\text { Management }\end{array}$ & $\begin{array}{l}\text { Designing of organization structure, making division of labour and recruiting } \\
\text { high quality employees }\end{array}$ \\
\hline EC & \multirow[b]{4}{*}{ FINANCE MANAGEMENT } & Equity Capital & $\begin{array}{l}\text { Having enough capital for sudden economical crisis that they can be face to } \\
\text { face on building up the business or after the beginning }\end{array}$ \\
\hline STL & & $\begin{array}{l}\text { Short-Term } \\
\text { Liabilities }\end{array}$ & Ensuring the payment of short-term liabilities on time \\
\hline CR & & Current Receivable & $\begin{array}{l}\text { Having ability for taking the current receivables as keeping the economic } \\
\text { balance of the company }\end{array}$ \\
\hline СM & & st Management & the cost of production, raw material and labour effectively \\
\hline
\end{tabular}

The comparison matrix (given Table 5.2) is formed by using the geometric mean given below: $\widetilde{\boldsymbol{a}}_{\mathrm{ij}}=\left(\mathbf{a}_{\mathrm{ij} 1} \otimes \mathbf{a}_{\mathrm{ij} 2} \otimes \ldots \otimes \mathbf{a}_{\mathrm{ij} 8}\right)$ for $\tilde{a}_{12}$ is given below: (sample calculation) 


$$
\begin{aligned}
\tilde{a}_{12} & =(0.167,0.20,0.25) \otimes(5,6,7) \otimes_{1} \ldots{ }^{\otimes}(1,1,1)^{1 / 8} \\
& =(0.937,1.115,1.283)
\end{aligned}
$$

\begin{tabular}{|c|c|c|c|c|c|c|c|c|c|c|c|c|}
\hline & A1 & A2 & A3 & A4 & A5 & A6 & A7 & As & Ag & $\mathrm{A} 10$ & A11 & A12 \\
\hline $\mathrm{A} 1$ & $(1,1,1)$ & $(0,937,1,1$ & $(0,218,0,264,0,316)$ & $(0,894,1,156,1,484)$ & $(1,060,1,275,1,507)$ & $(1,375,1,676,1,957)$ & $(0,343,0,429,0,546)$ & $(0.574,0,701,0.831)$ & $(0.284,0.338,0.427)$ & 10,375, & $(0,341,0$ & $(0.324,0,390,0.491)$ \\
\hline $\mathrm{A} 2$ & $(0,779,0.896,1,066)$ & $(1,1,1)$ & $(0.414,0.541,0.743)$ & $(0,712,0,853,1,076)$ & $(1,290,1,676,2,086)$ & $(1,598,2,070,2,632)$ & $(0,522,0,627,0.753)$ & $(0,683,0,860,1,060)$ & $(0.260,0.307,0.376)$ & $(0.443,0,541,0.707)$ & $(0.264,0.313,0.386)$ & $(0,304,0,367,0.466)$ \\
\hline A3 & $(4,738,5,441,6,128)$ & $(1.330,1,1640,1.956)$ & $(1,1,1)$ & $(2,8999,3.503,4.292)$ & $(4,413,5,430,6,441)$ & $(4.490,5.537,6.570)$ & $(2,118,2,502,2,851)$ & $(1,345,1,729,2,281)$ & $(0,337,0.432,0.613)$ & $(1,308,1,585,1,951)$ & $(1,065,1,463,2.069)$ & $(0,499,0,018,0,857)$ \\
\hline A4 & $(0,673,0.864,1,118)$ & $(0,928,1,171,1,1402)$ & $(0.233,0.285,0.344)$ & $(1,1,1)$ & $(1,017,1,359,1,746)$ & $(1,929,2,385,2,768)$ & $(0.575,0.723,0.884)$ & $(1,146,1,516,2,114)$ & $(0,318,0,404,0.513)$ & $(0.421,0.580,0.860)$ & $(0,598,0.737,0.898)$ & $(0,515,0,025,0,781)$ \\
\hline A5 & $(0.663,0.784,0.943)$ & $(0.479,0.596,0.774)$ & $(0,155,0.184,0.226)$ & $(0.572,0.735,0.983)$ & $(1,1,1)$ & $(1,846,2,103,2,332)$ & $(0,709,0,864,1.065)$ & $(0.917,1.206,1.545)$ & $(0.278,0,355,0.459)$ & $(0,677,0,884,1,267)$ & $(0,508,0.702,0,930)$ & $(0,537,0,068,0,840)$ \\
\hline $\mathrm{A} 6$ & 10.511 & $(0,380,0,48$ & 10.152 & $(1,57$ & 10.32 & $(1,1,1)$ & 10.357 & 194) & $0.462)$ & 10.2 & 0.499 & 10.3 \\
\hline $\mathrm{A} 7$ & $(1,715,2,213,2,790)$ & $(1,326,1,593,1,913)$ & $(0,350,0,399,0,471)$ & $(1,130,1,383,1,740)$ & $(0,938,1,157,1,409)$ & $(1,983,2,371,2,800)$ & $(1,1,1)$ & $(1,795,2,328,2,874)$ & $(0.394,0.447,0.518)$ & $(0,825,0,924,1,028)$ & $(0,728,0,840,1,042)$ & $(0.511,0.575,0.660)$ \\
\hline A8 & $(1,202,1.426,1.740)$ & $(0.942,1,162,1.463)$ & $(0.438,0.578,0.743)$ & $(0.472,0.659,0.871)$ & $(1,646,0.828,1.090)$ & $(0,836,1,051,1,350)$ & $(0.347,0.429,0.556)$ & $(1,1,1)$ & $(0.556,0.680,0.885)$ & $(0,932,1,121,1,326)$ & $(0,554,0.698,0.860)$ & $(0,385,0.464,0.575)$ \\
\hline A9 & $(2.339,2.956,3.515)$ & $(2,655,3,253,3,833)$ & $(1,629,2,309,2,962)$ & $(1,948,2,470,3,147)$ & $(2,174,2,810,3.587)$ & $(2,163,2.737,3,356)$ & $(1,929,2,236,2.539)$ & $(1,130,1,469,1,795)$ & $(1,1,1)$ & $(2,861,3,406,3,912)$ & $(2,213,2,854,3,413)$ & $(2,289,2,860,3,481)$ \\
\hline $\mathrm{A} 10$ & $(1,333,1,897,2,661)$ & $(1,414,1,846,2,256)$ & $(0.512,0,630,0.764)$ & $(1,162,1,721,2,374)$ & $(0,788,1,130,1,475)$ & $(1,861,2,671,3,430)$ & $(0.972,1.081,1.212)$ & $(0.753,0.891,1,072)$ & $(0.255,0.293,0.349)$ & $(1,1,1)$ & $(0,578,0,696,0,840)$ & $(0,585,0.712,0.884)$ \\
\hline A11 & $(1,886,2,449,2,930)$ & $(2,588,3,184,3.7777)$ & $(0,483,0,683,0.938)$ & $(1,112,1,355,1,673)$ & $(1,074,1,423,1,966)$ & $(2,003,2.530,3.074)$ & $(0.958,1.189,1,372)$ & $(1,162,1,431,1,803)$ & $(0.292,0.350,0.452)$ & $(1,189,1,435,1,729)$ & $(1,1,1)$ & $(1,423,1,1649,1,864)$ \\
\hline A12 & $(2.035,2,559,3.080)$ & $(2,146,2,723,3,289)$ & $(1,166,1,616,2,003)$ & $(1,279,1.599,1,939)$ & $(1,189,1,495,1,861)$ & $(1,549,2,059,2,638)$ & $(1,512,1.738,1,957)$ & $(1,738,2,153,2,595)$ & $(0.287,0.349,0.436)$ & $(1,036,1,222,1,435)$ & $(0,536,0,606,0,702)$ & $(1,1,1)$ \\
\hline
\end{tabular}

Table 5.2 Comparison Matrix

In order to determine the fuzzy weights of criteria, the computational procedures are

displayed as following parts

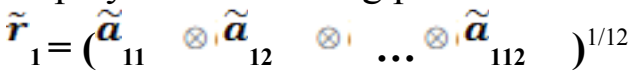

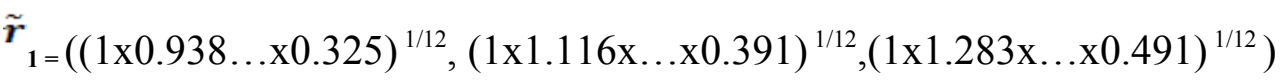

$$
\begin{aligned}
& \tilde{r}_{1=}(0.595,0.710,0.848) \\
& \widetilde{w}_{i} \text { values are calculated as below: }
\end{aligned}
$$

$\left.\widetilde{\boldsymbol{w}}_{1}=\widetilde{r}_{1} \otimes{ }_{1} \tilde{\boldsymbol{r}}_{1}^{\oplus} \tilde{\boldsymbol{r}}_{2}^{\oplus} \ldots{ }^{\oplus} \tilde{\boldsymbol{r}}_{112} \quad\right)^{-1}=(0.595,0.710,0.848){ }^{\otimes} 1 /(0.848+0.924+\ldots+1.655), 1 /$

$(0.710+0.766+\ldots+1.392)=(0.037,0.052,0.075)$

Last operation is related with the calculation of BNP values of each criterion. The procedures of: $B N P_{w 1}$ is given as below

$$
\begin{aligned}
B_{N P_{w 1}} & =\left[\left(U_{w 1}-L_{w 1}\right)+\left(M_{w 1}-L_{w 1}\right)\right] / 3+L_{w 1} \\
& =[(0.075-0.036)+(0.052-0.036)] / 3+0.036 \\
& =0.055
\end{aligned}
$$

General table regarding with the weights of dimensions are given as Table 5.3.

Table 5.3 Ranking Values of Criteria

\begin{tabular}{|l|c|c|}
\multicolumn{1}{c|}{ Criterion } & BNP & Rank \\
\hline Delivery Efficiency & 0,055 & 11 \\
\hline Competition Analysis & 0,059 & 9 \\
\hline Marketing-Advertising Management & 0,154 & 2 \\
\hline Customer Availability & 0,067 & 7 \\
\hline Production/Service System & 0,058 & 10 \\
\hline Supplying of Raw Material & 0,043 & 12 \\
\hline Product Quality & 0,087 & 5 \\
\hline Human Resource Management & 0,065 & $\mathbf{8}$ \\
\hline Equity Capital & 0,168 & 1 \\
\hline Short-Term Liabilities & 0,082 & 6 \\
\hline Current Receivable & 0,100 & 4 \\
\hline Cost Management & 0,107 & 3 \\
\hline
\end{tabular}

\section{Step:2 Comparing the criteria in various sector with Fuzzy TOPSIS}

Fuzzy decision matrix of TOPSIS method is constructed as choosing the appropriate linguistic variables for the alternatives with respect to the criteria in three sector called food production / service, textile industry and machine-equipment manufacturing. 
The evaluators (four evaluators in each category) make assesments for the criteria in each sector (each evaluator each sector or experts in all area) according to the linguistic terms including very poor, poor, fair, good and very good to explain their ideas The fuzzy decision matrix of Table 5.4 is constructed after calculating the arithmetic average of the comment points.

\begin{tabular}{|c|c|c|}
\hline & $\begin{array}{l}\text { Food } \\
\text { Production } \\
\text { IService }\end{array}$ & $\begin{array}{c}\text { Machine } \\
\text { Textile Equipment } \\
\text { ind ustry Manufacturing }\end{array}$ \\
\hline$\frac{d i-}{d i+}$ & \begin{tabular}{l|}
0.692 \\
0.447
\end{tabular} & \begin{tabular}{|l|l|}
0.702 \\
0.436 \\
\end{tabular} \\
\hline $\bar{c}_{i}=$ & 0.607 & \begin{tabular}{|l|l}
0.617 \\
\end{tabular} \\
\hline $\overrightarrow{c i t} i f$ & 0.393 & 0.383 \\
\hline
\end{tabular}

\section{Limitations}

In this study, ranking the criteria of the difficulties that entrepreneurs are face to face in their daily business life are completed with Fuzzy AHP and assessed in three sectors with Fuzzy TOPSIS. Generally, eight participants for Fuzzy AHP application and participants of only three sectors could weaken the value of the model. In this case, providing more participants in applications might add value and strengthen the reliability of the model.

\section{Conclusions}

In this study,the model regarding with integrating of Fuzzy AHP and TOPSIS methods is used to analyze the problem criteria of enterpreneurship and make assessment the criteria in various sectors.

The criteria are ranked as their importance according to the evaluators assessments and the most important criterion is determined as equity capital by using Fuzzy AHP method. Moreover, the last priority of these criteria is supplying of raw material. According to the results, three sectors including with food production/service, textile industry and machineequipment manufacturing are discussed with the enterpreneurs taking part in related sectors. After analysis of each sector by using Fuzzy TOPSIS method (with using the weights criteria determined in Fuzzy AHP method), machine-equipment manufacturing has biggest importance values at the point of facing serious problems and food production/service has less values. This model proposes an integration with fuzzy AHP and TOPSIS and presents real results for the analyzing of the enterpreneurship problems also assessment between different sectors. Especially, the importance of criteria enables the general vision for the problems of enterpreneurship processes. On the other hand, the area of study can be enlarged in various sectors and found out the comparative results.

\section{Key References}

[1] Cristea, A.,Vasile, V.,Zaman, G.,2012, Outstanding Aspects of Sustainable Development and Competitiveness Challenges for Entrepreneurship in Romania, International Conference Emerging Markets Queries in Finance and Business, Petru, 3,12-17

[2] Zahra, S.,Hayton, J.,Marcel, J.,O’Neill, H.,2001, Fostering Entrepreneurship During International Expansion:Managing Key Challenges,European Management Journal,19,359-369

[3] Göksu A. ve G.İbrahim, Application of Fuzzy AHP on Ranking of University Preferences Süleyman Demirel University, Journal of Faculty of Economics and Administrative Sciences Y.2008,C.13,S.3 s.1-26

[4] Wei, C. C., Chien, C., \& Wang, M. J. (2005). An AHP-based approach to ERP system selection. International Journal of Production Economics, 96, 47-62.

[5] Perry, M., Sohal, A. S., \& Rumpf, P. (1999). Quick response supply chain alliances in the Australian textiles, clothing and footwear industry. International Journal of Production Economics, 62, 119-132.

[6]Chan, F. T. S., \& Kumar, N. (2007). Global supplier development considering risk factors using fuzzy extended AHP-based approach. OMEGA, 35, 417-431. 
[7] Büyüközkan, G., Feyzioglu, O., \& Nebol, E. (2008). Selection of the strategic alliancepartner in logistics value chain. International Journal of Production Economics, 113, 148-158.

[8] Robbins K.D., Pearce A.J.,1993 Entrepreneurial retrenchment among small manufacturing firms, Journal of Business Venturing, 301-308 